\title{
Studies on the Suppression of Immune Responses by the Periwinkle Alkaloids Vincristine and Vinblastine*
}

\author{
Alan C. Aisenberg and Barbara Wilkes \\ (From the John Collins Warren Laboratories of the Huntington Memorial Hospital of \\ Harvard University at the Massachusetts General Hospital, Boston, Mass.)
}

It has been possible to achieve chemical suppression of immunological responsiveness by several classes of compounds. The most successful drugs used in the past have been the alkylating agents (1), the antipurines (2), the folic acid antagonists $(3,4)$, and actinomycin $\mathrm{D}(5,6)$. Further study of the problem of chemical immune suppression is warranted both because of the fundamental information about immune responsiveness that may be gained from such investigations and because of the continuing clinical need for effective agents.

In the present report we described our results in the rat with vincristine and vinblastine, ${ }^{1}$ examples of a new class of immunosuppressive drugs (7). Derived from the common periwinkle plant Vinca rosea and chemically characterized as dimeric alkaloids containing both the indole and dihydroindole moieties (8), the compounds were discovered independently by Noble, Beer, and Cutts $(9)^{2}$ and a group of investigators including Johnson, Armstrong, Gorman, and Burnett (8, 10). ${ }^{3} \quad$ Because these drugs have been shown to be effective against a variety of experimental (11) and human lymphoid neoplasms $(8,12,13)$, it appeared logical to try them as inhibitors of immune responses. We have found that not only do they inhibit antibody formation, delayed hypersensitivity, and homograft rejection, but they promptly suppress established delayed hypersensitivity. Furthermore, since one of the drugs

\footnotetext{
* Submitted for publication November 13, 1963; accepted August 28, 1964.

This investigation was supported by grant CA-07179 from the National Cancer Institute. This is publication no. 1185 of the Cancer Commission of Harvard University.

${ }^{1}$ Both obtained from Lilly Laboratories, Indianapolis, Ind.

2 At the University of Western Ontario, London, Ont.

3 At Lilly Laboratories, Indianapolis, Ind.
}

(vinblastine) produces marked leukopenia and the other (vincristine) does not (8), an opportunity was afforded to assess the role of the circulating lymphocyte in the several forms of immune responsiveness.

\section{Methods}

Immunization. Male inbred Fischer rats weighing 120 to $135 \mathrm{~g}$ were used for the experiments described in Tables I, II, and III, experiment 1 of Table IV, and the first experiment of Table VI. The remaining experiments were done with non-inbred Sprague-Dawley rats of the same age and sex. ${ }^{4}$ Animals were immunized to bovine serum albumin (BSA) and tuberculin [old tuberculin (OT)] by the injection into a rear foot pad (14) of $0.1 \mathrm{ml}$ of Freund's adjuvant, containing 0.5 $\mathrm{mg}$ bovine serum albumin and $0.3 \mathrm{mg}$ killed whole tubercle bacilli. Delayed hypersensitivity and Arthus reactivity were evaluated by the intradermal injection of $0.1 \mathrm{ml}$ of saline containing $30 \mu \mathrm{g}$ of bovine serum albumin and 0.1 $\mathrm{ml}$ of a 1 to 10 saline dilution of OT into opposite shaved and depilated (Nair) flanks. The figures for delayed hypersensitivity recorded in the tables are the average diameter of induration of the skin test 24 hours after testing, and the Arthus reactions represent the induration 4 hours after testing. (Although we record average induration of $2 \mathrm{~mm}$, probably $3 \mathrm{~mm}$ is the minimal significant reaction). Antibody formation to bovine serum albumin was measured in sheep cell-absorbed serum obtained from tail blood with tanned, formalinized sheep cells and the Microtiter apparatus (15). Fresh sheep cells ${ }^{5}$ were formalinized, tanned, and coated with $0.5 \mathrm{mg}$ bovine serum albumin per $\mathrm{ml}$ cells (16). The initial serum dilution was 1 to 4 . Other details of sensitization and testing were the same as those of Jankovic, Waksman, and Arnason (14).

Skin grafting. Conventional full-thickness skin grafting technique was employed (17). Casts were removed at 4 to 6 days, and autografts and homografts (two per recipient) were examined at that time, at 10 or 12 days, and every 2 to 3 days thereafter. The time of rejection was estimated visually as the time of the first graft changes that later went on to complete rejection.

4 All animals were obtained from the Charles River Breeding Laboratories, North Wilmington, Mass.

5 Obtained from the Cappel Laboratories, West Chester, $\mathrm{Pa}$. 


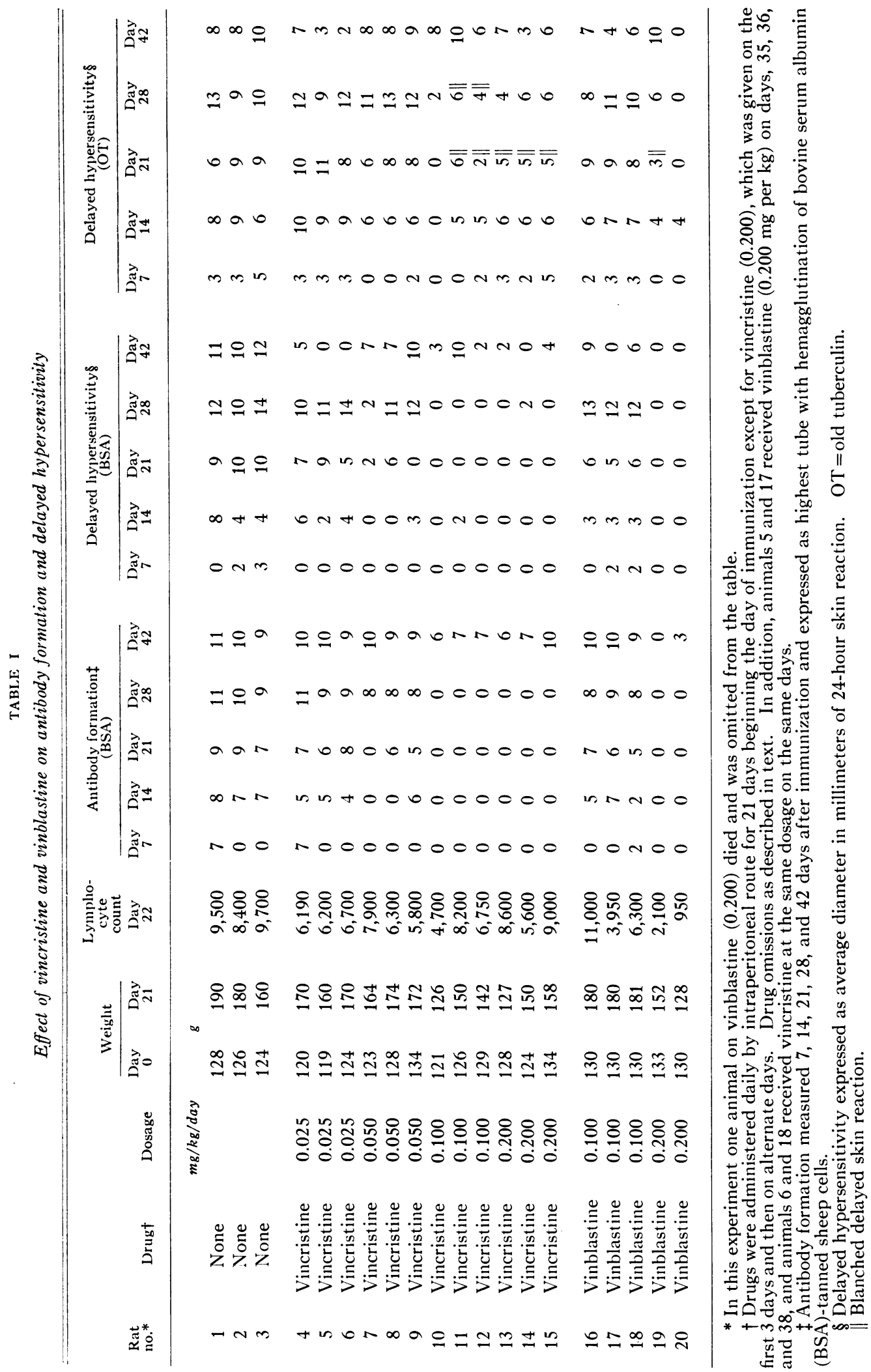


Microscopic study was not done. No difficulty was experienced in estimating the day of rejection except in the case of several drug-treated animals who rejected after day 30 and in whom a subtle and protracted graft rejection took place over a 5- to 7-day period. A single donor animal was used to supply the grafts for each of the grafting experiments.

Drug administration. In Fischer and Sprague-Dawley rats vincristine and vinblastine administration at the level of $0.100 \mathrm{mg}$ per $\mathrm{kg}$ for 21 days is usually well tolerated. For maximal immune suppression, particularly necessary for depression of homograft rejection, higher drug dosage is required, and we have found it advisable to weigh the animal before each injection and omit the drug in the face of excessive weight loss. We have injected only by intraperitoneal route and have found that peritoneal irritation is reduced when the drug is injected in a large volume of saline (usually about $1.0 \mathrm{ml}$ ). We have not experimented widely with the drug regimen, and it is quite likely that our schedule is not optimal.

Miscellaneous. Leukocyte counts and differential blood smears were done on tail blood using standard clinical techniques. Lymphocyte size was determined on smears stained with Wright's stain by micrometer measurement of individual cell diameters (at least 100 cells counted). Cells $11 \mu$ or larger were considered large lymphocytes, those 8.5 to $11 \mu$ medium lymphocytes, and those below $8.5 \mu$ small lymphocytes. Banal inflammation was determined by the intradermal injection into one shaved flank of $0.05 \mathrm{ml}$ of turpentine $(1: 20$ in olive oil), and the induration of the resulting inflammatory response was read at 24 hours.

\section{Results}

Effect on sensitization with bovine serum albu$\min (B S A)$ and tuberculin. Table I presents our results when vincristine and vinblastine administration is begun at the same time as the bovine serum albumin-Freund's adjuvant injection and continued for 21 days. Animals continued to gain weight during the experiment, although in the case of the higher drug levels the gain was less than untreated controls. Lymphocyte counts performed on the morning after the last injection of drug showed equivocal depression from control levels except in the case of vinblastine $(0.200 \mathrm{mg}$ per $\mathrm{kg}$ ), where marked lymphocyte depression was observed.

At high drug levels, vincristine $(0.100$ and $0.200 \mathrm{mg}$ per $\mathrm{kg})$ and vinblastine $(0.200 \mathrm{mg}$ per $\mathrm{kg}$ ), suppression of antibody formation and delayed hypersensitivity to bovine serum albumin were complete during the period of drug administration. In the same animals that showed complete depression of the bovine serum albumin response, however, depression of tuberculin sensitivity was only partial. (Some of the drugtreated animals showed minimal tuberculin reactions that possessed a peculiar blanched quality). Lower dosage of drug, vincristine (0.025 and $0.050 \mathrm{mg}$ per $\mathrm{kg})$ and vinblastine $(0.100 \mathrm{mg}$ per $\mathrm{kg}$ ), caused partial suppression of immune responses, and in general, the suppression of antibody and of delayed hypersensitivity to bovine serum albumin closely paralleled each other in the particular animal. Seven days after stopping the drugs immune suppression remained, but after 3 weeks antibody formation and minimal delayed reactions to bovine serum albumin appeared in the vincristine animals and in one vinblastine animal.

Without histological study, it is possible that the 24-hour reactions of Table I may be caused in part by immediate-type hypersensitivity. Such an occurrence could account for the greater depression of bovine serum albumin hypersensitivity observed. However, careful examination of the 24-hour rat skin reaction both to bovine serum albumin and tuberculin has revealed histology that other investigators (14) have concluded is typical of delayed reactions.

As a preliminary experiment (Table I), four animals were selected after the development of good delayed reactions and given vinblastine (no. 5 and 17) and vincristine (no. 6 and 18) at the $0.200 \mathrm{mg}$ per $\mathrm{kg}$ level on days 35. 36, and 38 . When compared with control rats (no. 4 and 16), there was partial suppression of delayed hypersensitivity in these animals but no fall in antibody level.

Suppression of established delayed hypersensitivity. In the experiment described in Table II, animals received varying doses of vincristine and vinblastine over a 3- to 7-day period. 21 days after immunization with bovine serum albumin in Freund's adjuvant, and after skin testing and lymphocyte counts. Repeat testing and lymphocyte counts were performed on days $3,5,8$, and 16 after the initial drug dose. Not included in Table II are three control animals that displayed essentially constant skin reaction during the period of skin testing.

On the day before drug administration all animals had good skin reactions to both antigens. By day 3 of the drug, two of the vincristine animals were already anergic to both antigens as was 
TABLE II

Effect of vinblastine and vincristine on established delayed hypersensitivity* and on lymphocyte counts

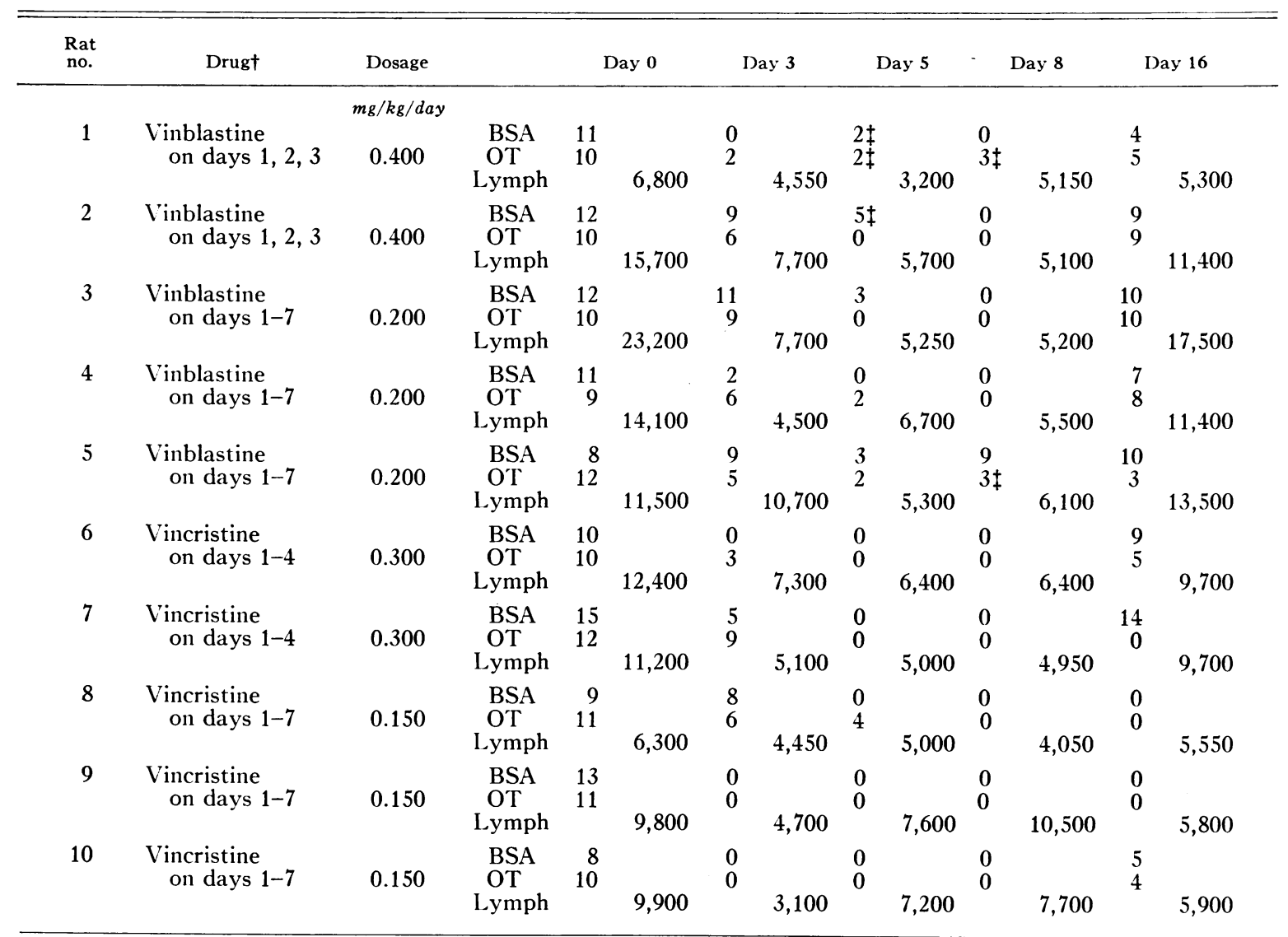

* Average diameter in millimeters of induration of a 24 -hour skin reaction.

$\dagger$ Drug was begun on day 1,21 days after immunization.

$\ddagger$ Blanched delayed skin reaction.

one of the vinblastine animals. By day 5 four vincristine and two vinblastine animals were unresponsive, and by day 8 all five vincristine and four of five vinblastine rats had lost their skin reactions. Recovery of skin reactivity, either partial or complete, had occurred by day 16 in all but two of the vincristine animals.

The treated animals displayed depression of lymphocyte count, greater in the vinblastine animals (higher drug dosage) than in the vincristine ones (Table II). The depression was for the most part not profound and had usually recovered by day 16. Although there was some depression in the counts in all the anergic animals, generally there was no close parallel between skin reactivity and lymphocyte count. Differential lymphocyte counts on a selected group of animals from Table
II are presented in Table III. Again, the correlation is not close between the depression of lymphocytes of any particular size with the loss of delayed hypersensitivity.

Arthus reaction and banal inflammation. Table IV presents data from three experiments designed to study the effect of vincristine on Arthus reactivity and banal inflammation. Twenty-one days after immunization with Freund's-bovine serum albumin and after preliminary skin testing and antibody determination, vincristine was administered at high dosage for 3 days. Further testing and antibody determinations were done as indicated in the table. Three control animals employed for each experiment (omitted from the table) received no drug and displayed no significant changes in any of the parameters studied dur- 
TABLE III

Differential lymphocyte* counts in rats on vincristine

\begin{tabular}{|c|c|c|c|c|c|c|c|c|c|c|c|c|}
\hline \multirow{2}{*}{$\underset{\text { no. } t}{\text { Animal }}$} & \multicolumn{3}{|c|}{ Day 0} & \multicolumn{3}{|c|}{ Day 3} & \multicolumn{3}{|c|}{ Day 5} & \multicolumn{3}{|c|}{ Day 8} \\
\hline & Small & Medium & Large & Small & Medium & Large & Small & Medium & Large & Small & Medium & Large \\
\hline 6 & 7.0 & 4.2 & 1.2 & 3.2 & 3.5 & 0.6 & 2.1 & 1.2 & 0.4 & 3.5 & 2.6 & 0.5 \\
\hline 7 & 3.1 & 5.8 & 2.2 & 2.0 & 2.6 & 0.4 & 1.5 & 2.5 & 1.0 & 3.4 & 1.1 & 0.5 \\
\hline 8 & 2.5 & 2.3 & 1.5 & 1.2 & 2.4 & 0.8 & 1.8 & 2.1 & 1.1 & 2.3 & 1.1 & 0.7 \\
\hline 9 & 5.8 & 2.8 & 1.4 & 3.1 & 1.2 & 0.4 & 3.4 & 3.2 & 1.1 & 4.2 & 4.6 & 1.2 \\
\hline 10 & 2.0 & 5.8 & 2.2 & 1.6 & 0.9 & 0.6 & 2.9 & 3.2 & 1.2 & 2.5 & 3.1 & 2.2 \\
\hline
\end{tabular}

* Lymphocyte counts $\times 10^{-3}$.

$\dagger$ Refer to animals in Table II.

ing the experiment. Depression of the Arthus reaction was seen in all three experiments, but even at the high drug dosage employed the depression was not so complete as the depression of delayed hypersensitivity. Thus, of 12 animals on whom the data are complete, nine showed significant depression of the Arthus reaction. Of these nine, four displayed significant depression of antibody titers from the pretreatment levels, and the other five showed essentially unchanged antibody level. In all the animals studied at 5 days there was some depression of the inflammatory response to injected turpentine. (The observed area of induration in untreated animals is at least $6 \mathrm{~mm}$ after the injection of turpentine under these conditions.)

Effect on antibody formation and hair growth of vincristine started at various times after immunization. Table $\mathrm{V}$ presents data on the effect on anti-bovine serum albumin antibody formation of vincristine begun on the day of immunization and 2, 4, and 7 days later. Immunization was again accomplished with bovine serum albumin in Freund's adjuvant, and the drug was continued for 11 days. Even when the drug was started as late as day 5, antibody did not appear during the period of drug administration. Of particular interest is the group of animals in which vincristine

TABLE IV

Effect of vincristine* on the Arthus reaction and on banal inflammation

\begin{tabular}{|c|c|c|c|c|c|c|c|c|c|c|c|c|c|c|c|c|}
\hline & \multicolumn{5}{|c|}{ Day 0} & \multicolumn{2}{|c|}{ Day 3} & \multicolumn{5}{|c|}{ Day 5} & \multicolumn{4}{|c|}{ Day 8} \\
\hline & B & $\mathrm{S}$ & $\mathbf{A}$ & & & B & A & B & $\mathrm{S}$ & A & & & B & $\mathrm{S}$ & A & \\
\hline & Arthus $\dagger$ & Delayed $\ddagger$ & $\begin{array}{l}\text { Anti- } \\
\text { body }\end{array}$ & OT $\ddagger$ & $\begin{array}{l}\text { pen- } \\
\text { tinet }\end{array}$ & Arthus $\dagger$ & Delayed $\ddagger$ & Arthus $\dagger$ & Delayed $\ddagger$ & $\begin{array}{l}\text { Anti- } \\
\text { body }\end{array}$ & OT & pen- & Arthus† & Delayed $\ddagger$ & $\begin{array}{l}\text { Anti- } \\
\text { body }\end{array}$ & $\begin{array}{l}\text { pen- } \\
\text { tinef }\end{array}$ \\
\hline \multicolumn{17}{|l|}{ Exp. 1} \\
\hline No. 1 & 0 & 11 & 5 & & & 0 & 5 & 0 & 0 & & & & 0 & 0 & 6 & 5 \\
\hline No. 2 & 7 & 11 & 8 & & & 11 & 9 & 7 & 0 & & & & 7 & 9 & 7 & 6 \\
\hline No. 3 & 7 & 9 & 9 & & & 1 & 0 & 0 & 0 & & & & 0 & 0 & 4 & 5 \\
\hline No. 4 & 4 & 8 & 11 & & & 6 & 0 & 0 & 0 & & & & 0 & 0 & 11 & 5 \\
\hline No. 5 & 5 & 9 & 11 & & & 10 & 0 & 10 & 0 & & & & 10 & 5 & 11 & 5 \\
\hline \multicolumn{17}{|l|}{ Exp. 2} \\
\hline No. 1 & 8 & 10 & 10 & & & 9 & 0 & 0 & 0 & & & 3 & 0 & 0 & 7 & 5 \\
\hline No. 2 & 12 & 8 & 11 & & & 14 & 9 & 0 & 0 & & & 2 & 0 & 0 & 7 & 8 \\
\hline No. 3 & 10 & 10 & 12 & & & 8 & 10 & 5 & 8 & & & 5 & 5 & 10 & 12 & 6 \\
\hline No. 4 & 12 & 9 & & & & 10 & 0 & 10 & 0 & & & 0 & $\S$ & $\S$ & $\S$ & $\S$ \\
\hline \multicolumn{17}{|l|}{ Exp. 3} \\
\hline No. 1 & 20 & 15 & 9 & 8 & 9 & & & 2 & 0 & 9 & 0 & 4 & & & & \\
\hline No. 2 & 22 & 13 & 11 & 7 & 6 & & & 5 & 0 & 9 & 0 & 5 & & & & \\
\hline No. 3 & 20 & 13 & 10 & 11 & 8 & & & 6 & 0 & 10 & 0 & 5 & & & & \\
\hline No. 4 & 20 & 11 & 10 & 10 & 9 & & & 15 & 9 & 9 & 0 & 4 & & & & \\
\hline No. 5 & 20 & 10 & 11 & 6 & 6 & & & 4 & $\S$ & 8 & 0 & $\S$ & & & & \\
\hline No. 6 & 18 & 9 & & 4 & 7 & & & 2 & $\S$ & $\S$ & $\S$ & $\S$ & & & & \\
\hline
\end{tabular}

* Vincristine, $0.4 \mathrm{mg}$ per $\mathrm{kg}$, was given for 3 days (days 1, 2, and 3) 21 days after immunization with Freund's adjuvant-BSA.

t Average diameter in millimeters of 4-hour skin reaction.

Average diameter in millimeters of induration of 24 -hour skin reaction.

$\$$ Animal dead. 
TABLE V

Effect of vincristine* started various times after immunization on antibody formation

\begin{tabular}{|c|c|c|c|c|c|c|c|c|c|c|c|c|c|}
\hline \multirow{2}{*}{$\begin{array}{l}\text { Drug } \\
\text { group }\end{array}$} & \multirow{2}{*}{$\begin{array}{l}\text { Rat } \\
\text { no. }\end{array}$} & \multicolumn{12}{|c|}{ Day after immunization } \\
\hline & & 0 & 2 & 4 & 7 & 10 & 12 & 14 & 17 & 21 & 24 & 29 & 35 \\
\hline $\begin{array}{l}\text { Group I } \\
\text { (No drug) }\end{array}$ & $\begin{array}{l}1 \\
2 \\
3\end{array}$ & $\begin{array}{l}0 \\
0 \\
0\end{array}$ & & & $\begin{array}{l}5 \dagger \\
6 \dagger \\
9 \dagger\end{array}$ & $\begin{array}{l}5 \\
7 \\
7\end{array}$ & & $\begin{array}{r}7 \dagger \\
10 \dagger \\
9 \dagger\end{array}$ & $\begin{array}{l}6 \\
9 \\
7\end{array}$ & $\begin{array}{r}8 \\
11 \\
10\end{array}$ & $\begin{array}{l}11 \dagger \\
11 \dagger \\
11 \dagger\end{array}$ & $\begin{array}{l}11 \\
11 \\
11\end{array}$ & $\begin{array}{r}10 \dagger \\
9 \dagger \\
10 \dagger\end{array}$ \\
\hline Group II & $\begin{array}{l}4 \\
5 \\
6\end{array}$ & $\begin{array}{l}0 \\
0 \\
0 \\
\end{array}$ & & & $\begin{array}{l}0 \dagger \\
0 \dagger \\
0 \dagger\end{array}$ & $\begin{array}{l}0 \\
0 \\
0\end{array}$ & & $\begin{array}{l}0 \\
0 \\
0\end{array}$ & $\begin{array}{l}1 \\
4 \\
5\end{array}$ & $\begin{array}{l}5 \\
8 \\
6\end{array}$ & $\begin{array}{l}7 \dagger \\
7 \dagger \\
6 \dagger\end{array}$ & $\begin{array}{l}9 \\
9 \\
8\end{array}$ & $\begin{array}{r}10 \dagger \\
10 \dagger \\
8 \dagger\end{array}$ \\
\hline Group III & $\begin{array}{l}7 \\
8 \\
9\end{array}$ & $\begin{array}{l}0 \\
0 \\
0\end{array}$ & & & $\begin{array}{l}0 \dagger \\
0 \dagger \\
0 \dagger\end{array}$ & $\begin{array}{l}0 \\
0 \\
0 \\
\end{array}$ & & $\begin{array}{l}0 \\
0 \\
0\end{array}$ & $\begin{array}{l}0 \\
0 \\
1\end{array}$ & $\begin{array}{l}4 \\
3 \\
5\end{array}$ & $\begin{array}{l}7 \\
7 \\
5\end{array}$ & $\begin{array}{l}8 \\
8 \\
8\end{array}$ & $\begin{array}{r}10 \dagger \\
8 \dagger \\
9 \dagger\end{array}$ \\
\hline Group IV & $\begin{array}{l}10 \\
11 \\
12\end{array}$ & $\begin{array}{l}0 \\
0 \\
0\end{array}$ & & & $\begin{array}{l}0 \dagger \\
0 \dagger \\
0 \dagger\end{array}$ & $\begin{array}{l}0 \\
0 \\
0 \\
\end{array}$ & & $\begin{array}{l}0 \\
0 \\
0 \\
\end{array}$ & $\begin{array}{l}0 \\
0 \\
0\end{array}$ & $\begin{array}{l}3 \\
0 \\
0\end{array}$ & $\begin{array}{l}7 \\
6 \\
5\end{array}$ & $\begin{array}{l}7 \\
7 \\
5\end{array}$ & $\begin{array}{r}6 \dagger \\
10 \dagger \\
9 \dagger\end{array}$ \\
\hline Group V & $\begin{array}{l}13 \\
14 \\
15 \\
16\end{array}$ & $\begin{array}{l}0 \\
0 \\
0 \\
0\end{array}$ & & & $\begin{array}{l}6 \dagger \\
5 \dagger \\
7 \dagger \\
5 \dagger\end{array}$ & $\begin{array}{l}5 \\
4 \\
5 \\
5\end{array}$ & & $\begin{array}{l}0 \\
0 \\
0 \\
0\end{array}$ & $\begin{array}{l}0 \\
0 \\
0 \\
0\end{array}$ & $\begin{array}{l}0 \\
1 \\
1 \\
1\end{array}$ & $\begin{array}{l}5 \\
2 \\
2 \\
5\end{array}$ & $\begin{array}{l}8 \\
7 \\
5 \\
7\end{array}$ & $\begin{array}{l}8 \\
8 \\
8 \\
7\end{array}$ \\
\hline
\end{tabular}

* The period of vincristine administration was 11 days in duration at a level of $0.2 \mathrm{mg}$ per $\mathrm{kg}$ per day and has been ellclosed within a rectangle. Vincristine was begun on the day of immunization with BSA (day 0 ) in group II, on day 2 in group III, on day 4 in group IV, and on day 7 in group V.

$\dagger$ Indicates day on which shaving and depilation were required for skin testing.

was started on day 7 after immunization, after antibody had appeared (group V). An abrupt cessation of antibody formation must occur when the drug is given, since after 7 days of treatment anti-bovine serum albumin antibody had disappeared from the blood of group V animals. Antibody formation begins in the various drug-treated animals about 7 to 10 days after the cessation of vincristine injections. Both immediate (Arthus) and delayed skin reactions were determined in the animals presented in Table $\mathrm{V}$, but they are not included in the table. Arthus reactivity appeared for the first time about 2 weeks after the drug was stopped at a time when antibody levels were high, but delayed reactions appeared somewhat later and were never of more than moderate intensity $(6 \mathrm{~mm}$ in diameter or less). In the course of shaving and depilating the animals for skin testing, a particularly interesting observation of the effect of vincristine on hair growth was made. The days on which it was necessary to shave the animals for skin testing are indicated in Table V. Although control animals required shaving every 7 to 10 days, animals on vincristine did not require shaving while on the drug. As indicated in the table, it was only some 2 to 3 weeks after the cessation of drug that shaving was again necessary. Thus the resumption of hair growth parallels the resumption of immunological reactivity.

Skin grafting. Table VI indicates that the periwinkle drugs also suppress the homograft reaction, although only at levels where drug toxicity and mortality are high. Control Sprague-

TABLE VI

\begin{tabular}{|c|c|c|c|c|}
\hline & $\begin{array}{l}\text { Day } \\
\text { exam- } \\
\text { ined }\end{array}$ & $\begin{array}{l}\text { Con- } \\
\text { trol }\end{array}$ & $\begin{array}{l}\text { Vin- } \\
\text { cristine }\end{array}$ & $\begin{array}{c}\text { Vin- } \\
\text { blastine }\end{array}$ \\
\hline Total drug deaths & $\begin{array}{r}0 \\
10 \\
13 \\
15 \\
18 \\
30\end{array}$ & $\begin{array}{l}6 \\
0 \\
0 \\
0 \\
0 \\
0\end{array}$ & $\begin{array}{l}8 \\
8 \\
7 \\
3 \\
2 \\
1(18) \\
3\end{array}$ & $\begin{array}{l}7 \\
7 \\
6 \\
3 \\
1 \\
1 \\
3\end{array}$ \\
\hline $\begin{array}{l}\text { Sprague-Dawley } \\
\text { to Sprague-Dawley }\end{array}$ & $\begin{array}{r}0 \\
12 \\
14 \\
16 \\
20 \\
30\end{array}$ & $\begin{array}{l}\mathbf{5} \\
0 \\
0 \\
0 \\
\mathbf{0} \\
\mathbf{0}\end{array}$ & $\begin{array}{l}9 \\
5 \ddagger \\
5 \\
4 \\
4 \\
3(14) \\
1\end{array}$ & $\begin{array}{l}6 \\
2 \\
2 \\
2 \\
1 \\
0(27) \\
2\end{array}$ \\
\hline
\end{tabular}

* Drug administered, $0.2 \mathrm{mg}$ per $\mathrm{kg}$ per day for 21 days, beginning with day of grafting with omissions as described in text.

t Expressed as animals with intact homografts. A number in parentheses represents the day of death of one animal with intact graft. $\ddagger$ Loss of grafts in two animals may be related to loss of protecting
plaster cast within 24 hours of grafting. 
Dawley to Fischer grafts were rejected by day 10 , whereas three animals in each of the vincristine and vinblastine groups retained the grafts for 15 days. Since only one animal in each treated group had failed to reject his graft by day 30 , homografting within the non-inbred SpragueDawley strain was tried. The suppression of Sprague-Dawley to Sprague-Dawley graft rejection was more successful with vincristine: three of nine grafts survived 30 days with only one drug death. (Control Sprague-Dawley to Sprague-Dawley grafts were rejected by day 12.) The drugs were continued only to day 21 , and grafts surviving at 30 days underwent a slow rejection some time between days 30 and 45 .

\section{Discussion}

The inhibitory activity of vincristine and vinblastine against cells of the lymphoid line made it likely a priori that they would be active immunosuppressive agents. Although other investigators have reported negative results with vincaleukoblastine (18-20), the present experiments indicate that immunological suppression can be produced in the rat with the periwinkle alkaloids under appropriate conditions. Delayed hypersensitivity and antibody formation are completely inhibited when these drugs are started at the same time as immunization with bovine serum albumin in Freund's adjuvant. Quite striking is the suppression of established delayed hypersensitivity and the prompt cessation of the early stages of antibody formation that occur after the administration of vincristine. Finally, although less complete than the suppression of antibody formation and delayed hypersensitivity, definite diminution of Arthus reactivity and delay of homograft rejection are observed with vincristine administration.

In attempting to define the mechanism of the immunosuppressive action of the periwinkle alkaloids on a cellular level, it seems most reasonable that the compounds act by inhibiting the proliferation of one or several cell types involved in the various forms of immune response. Evidence presently available suggests that delayed hypersensitivity is mediated by a circulating lymphoid cell, perhaps the small lymphocyte (21-24). Reasoning along these lines, we can suggest that the vincristine inhibition of delayed hypersensi- tivity involves either the inhibition of the generation of the sensitive cell from its immunologically uncommitted lymphoid precursor, or inhibition of the subsequent evolution of the fully developed mononuclear delayed response from this committed sensitive cell. Although this point can be settled definitively only by experiments involving transfer of delayed hypersensitivity with lymphoid cells (25), by analogy with the antibody results to be discussed in the following paragraph, we feel that it is more likely that vincristine interferes with the production of the specifically sensitized cell that mediates delayed hypersensitivity. Our inability to detect a close correlation between depression of a morphological class of lymphocytes and depression of established delayed hypersensitivity does not particularly prejudice the issue one way or the other, since peripheral lymphocytes are composed of several morphological and functional types $(24,26,27)$, and depression of a significant lymphocyte species could occur that would escape our gross techniques of lymphocyte enumeration.

The prompt cessation of antibody formation observed after vincristine administration is reasonably attributed to inhibition of the proliferation of the antibody-producing cells. The data, although not conclusive, suggest that antibody formation at its outset is more sensitive to vincristine inhibition than it is when well established (compare group V, Table V, with Table IV). This differential sensitivity could be related to the successive production of antibody by drug-sensitive immature lymphoid cells and drug-insensitive mature plasma cells (28), or to a change from the production of $19 \mathrm{~S}$ to $7 \mathrm{~S}$ antibody, or both. On the basis of the evidence herein presented this suggestion is speculative, but Sahiar and Schwartz have recently demonstrated a selective sensitivity of $7 \mathrm{~S}$ antibody formation to 6-mercaptopurine (29).

Vincristine also inhibits the inflammatory response to injected turpentine, another property it shares with 6-mercaptopurine (30). This antiinflammatory action of vincristine may contribute to the depression of delayed hypersensitivity, and the combination of anti-inflammatory effect, depression of polymorphonuclear leukocytes (8), and curtailment of antibody formation could explain the inhibition of Arthus reactivity observed. 
The anti-inflammatory action of the drug, however, cannot be responsible for the suppression of antibody formation, and we feel that of itself it is very unlikely that this anti-inflammatory effect accounts for the inhibition of delayed hypersensitivity. Certainly, the depression of delayed hypersensitivity is more intense and prolonged than the depression of turpentine inflammation (see Table III).

The parallel depression and recovery of immunological reactivity and hair growth give credence to the view that the immune suppression of vincristine is a manifestation of the inhibition of cell division of a number of drug-sensitive cell types. Cellular proliferation is intimately associated with immunological reactivity (31), and vincristine and vinblastine cause metaphase arrest in tissue culture (8). Thus the striking immunological impairment seen with vincristine could be reasonably attributed to the inhibition of proliferation of one or more types of immunologically competent lymphoid cells and a similar inhibition of the generation of inflammatory cells. The remarkable rapidity with which delayed hypersensitivity is suppressed and early antibody production ceases (Tables II and V) suggests, if such a mechanism is correct, that both are mediated by cells of very limited life span (a few days) in a state of rapid turnover. A life span of a few days has been attributed to antibody-forming cells from other data (31).

Other immunosuppressive agents studied to date have also been potent inhibitors of cell division and, like the periwinkle alkaloids, have been drawn from the field of cancer chemotherapy. On a biochemical level, this inhibition of mitosis has been mediated through a nucleic acid mechanism. Thus in the case of the alkylating agents (32), the antipurines (33), and the folic acid antagonists (34), inhibition of DNA synthesis appears to be responsible for the inhibition of mitosis, although an RNA mechanism has not been ruled out. The mechanism of action of actinomycin $\mathrm{D}$ is probably through DNA-dependent RNA synthesis (35). Although it is not unlikely that the periwinkle drugs act in the same manner as the other immunosuppressive agents, i.e., on nucleic acid synthesis, particularly synthesis of DNA, at present the evidence for this mechanism is preliminary (8).
It is also plausible that immunosuppressive agents exert their effect by inhibiting synthesis of the RNA template (messenger-RNA), as originally suggested by Schwartz, Eisner, and Dameshek (2). Finally, there is nothing to exclude the possibility of these drugs acting on both mitosis and template-RNA synthesis, a formulation that would help to explain the complexities of the suppression. Until more is known of the detailed biochemical events of immunological responsiveness, any proposed mechanism of immunological suppression must be tentative.

In the present experiments, with continuing stimulation of the original antigen-containing Freund's adjuvant, our animals displayed good antibody formation and modest delayed reactions to bovine serum albumin 2 to 3 weeks after the drug was stopped. Our failure to observe the tolerance seen in the 6-mercaptopurine system (36) is as likely attributable to a difference in the method of immunization (single intravenous injection in the case of 6-mercaptopurine), quantity of antigen, or of species, as to a fundamental difference in the mode of action of the several agents (37). Both 6-mercaptopurine $(2,38,39)$ and neonatal antigen exposure (40), like vincristine and vinblastine, inhibit antibody formation and delayed hypersensitivity to protein antigens and homograft rejection. As in neonatal tolerance $(40,41)$, we find suppression of reactivity to protein antigens more easily achieved than the suppression of hypersensitivity to tuberculin (Table I).

Whether the periwinkle drugs will prove of value in suppressing the homograft reaction in man is entirely speculative, since there has been marked species variation in the effectiveness of the known immunosuppressive agents $(37,40)$. The action of vincristine and vinblastine against human lymphoid neoplasms is encouraging, but in the rat at least, it has been more difficult to suppress the skin homograft reaction than other forms of immunological reactivity.

\section{Summary}

The dimeric alkaloids vincristine and vinblastine, derived from the periwinkle plant Vinca rosea, have been found to be potent immunosuppressive agents in the rat. When administered at 
the time of immunization with bovine serum albumin in complete Freund's adjuvant, antibody formation and delayed hypersensitivity to bovine serum albumin are completely suppressed, and hypersensitivity to tuberculin is markedly reduced. At high vincristine dosage, established delayed hypersensitivity to these antigens was promptly and regularly abolished, early antibody formation ceased, and homograft rejection was substantially delayed. Lesser degrees of inhibition of the inflammatory response to turpentine and Arthus reactivity were seen, and hair growth stopped while the drug was administered. A profound and consistent depression of small, medium, or large lymphocytes in the peripheral blood was not observed during immune suppression with vincristine. We felt that the mechanism of the immunosuppressive action of vincristine most likely involved inhibition of the proliferation of one or more immunologically competent lymphoid cells, probably through a DNA mechanism.

\section{Acknowledgment}

We are grateful to Dr. J. G. Armstrong of the Lilly Laboratories for the supply of vincristine.

\section{References}

1. Hektoen, L., and H. J. Corper. The effect of mustard gas (dichloroethylsulfide) on antibody formation. J. infect. Dis. 1921, 28, 279.

2. Schwartz, R., A. Eisner, and W. Dameshek. The effect of 6-mercaptopurine on primary and secondary immune responses. J. clin. Invest. 1959, 38, 1394.

3. Uphoff, D. E. Alteration of homograft reaction by A-methopterin in lethally irradiated mice treated with homologous marrow. Proc. Soc. exp. Biol. (N. Y.) 1958, 99, 651.

4. Friedman, R. M., C. E. Buckler, and S. Baron. The effect of aminomethylpteroylglutamic acid on the development of skin hypersensitivity and on antibody formation in guinea pigs. J. exp. Med. 1961, 114, 173.

5. Uhr, J. W. Actinomycin D: its effect on antibody formation in vitro. Science 1963, 142, 1476.

6. Wust, C. J., C. L. Gall, and G. D. Novelli. Actinomycin $\mathrm{D}$ : effect on immune response. Science 1964, 143, 1041.

7. Aisenberg, A. C. Suppression of immune response by "vincristine" and "vinblastine." Nature (Lond.) 1963, 200, 484.

8. Johnson, I. S., J. G. Armstrong, M. Gorman, and J. P. Burnett, Jr. The Vinca alkaloids: a new class of oncolytic agents. Cancer Res. 1963, 23, 1390.

9. Noble, R. L., C. T. Beer, and J. H. Cutts. Role of chance observation in chemotherapy: Vinca rosea. Ann. N. Y. Acad. Sci. 1958, 76, 882.

10. Johnson, I. S., H. F. Wright, G. H. Svoboda, and J. Vlantis. Antitumor principles derived from Vinca rosea Linn. I. Vincaleukoblastine and leurosine. Cancer Res. 1960, 20, 1016.

11. Johnson, I. S., H. F. Wright, and G. H. Svoboda. Experimental basis for clinical evaluation of antitumor principles derived from Vinca rosea Linn. J. Lab. clin. Med. 1959, 54, 830.

12. Hodes, M. E., R. J. Rohn, and W. H. Bond. Vincaleukoblastine. I. Preliminary clinical studies. Cancer Res. 1960, 20, 1041.

13. Warwick, O. H., R. E. Alison, and J. M. M. Darte. Clinical experience with vinblastine sulfate. Canad. med. Ass. J. 1961, 85, 579.

14. Jankovic, B. D., B. H. Waksman, and B. G. Arnason. Role of the thymus in immune reactions in rats. I. The immunologic response to bovine serum albumin (antibody formation, Arthus reactivity, and delayed hypersensitivity) in rats thymectomized and splenectomized at various times after birth. J. exp. Med. 1962, 116, 159.

15. Sever, J. L. Application of a microtechnique to viral serological investigations. J. Immunol. 1962, 88, 320.

16. Stavitsky, A. B., and E. R. Arquilla. Studies of proteins and antibodies by specific hemagglutination and hemolysis of protein-conjugated erythrocytes. Int. Arch. Allergy 1958, 13, 1.

17. Billingham, R. E. Free skin grafting in mammals in Transplantation of Tissues and Cells, R. E. Billingham and W. K. Silvers, Eds. Philadelphia, Wistar Institute Press, 1961, p. 1.

18. Maguire, H. C., Jr., and H. I. Maibach. Effect of cyclophosphoramide, 6-mercaptopurine, actinomycin $\mathrm{D}$ and vincaleukoblastine on the acquisition of delayed hypersensitivity (DCNB contact dermatitis) in the guinea-pig. J. invest. Derm. 1961, $37,427$.

19. Frenger, V. W., S. Witte, and S. Stafilidis. Zur Beeinflussung der serumantikörperbildung durch Zytostatika. Med. exp. (Basel) 1962, 7, 45.

20. Santos, G. W., and A. H. Owens, Jr. The effect of certain alkylating agents and antimetabolites on the primary agglutinin response in rats injected with sheep erythrocytes. Blood 1962, 20, 111.

21. Lawrence, H. S. The delayed type of allergic inflammatory response. Amer. J. Med. 1956, 20, 428.

22. Waksman, B. H. Delayed hypersensitive reactions: a growing class of immunologic phenomena. J. Allergy 1960, 31, 468.

23. Waksman, B. H., S. Arbouys, and B. G. Arnason. The use of specific "lymphocyte" antisera to inhibit hypersensitive reactions of the "delayed" type. J. exp. Med. 1961, 114, 997. 
24. Gowans, J. L., D. D. McGregor, D. M. Cowen, and C. E. Ford. Initiation of immune responses by small lymphocytes. Nature (Lond.) 1962, 196, 651.

25. Dixon, F. J., and W. O. Weigle. The nature of the immunologic inadecuacy of neonatal rabbits. II. Antibody formation by neonatal splenic cells transferred to adult recipients. J. exp. Med. 1959, $110,139$.

26. Ottesen, J. On the age of human white cells in peripheral blood. Acta physiol. scand. 1954, 32, 75.

27. Yoffey, J. M., and F. C. Courtice. Lymphatics, Lymph and Lymphoid Tissue. Cambridge, Mass., Harvard University Press, 1956, p. 408.

28. Leduc, E. H., A. H. Coons, and J. M. Connolly. Studies on antibody production. II. The primary and secondary responses in the popliteal lymph node of the rabbit. J. exp. Med. 1955, 102, 61 .

29. Sahiar, K., and R. Schwartz. Selective inhibition of 7S antibody synthesis by 6-mercaptopurine. Fed. Proc. 1964, 23, 190.

30. Page, A. R. Anti-inflammatory activity of 6-mercaptopurine. Fed. Proc. 1962, 21, 276.

31. Nossal, G. J. V. Cellular genetics of immune responses in Advances in Immunology, W. H. Taliaferro and J. H. Humphrey, Eds. New York, Academic Press, 1962, vol. 2, p. 163.

32. Ross, W. C. J. Biological Alkylating Agents. London, Butterworths, 1962, p. 79.

33. Brockman, R. W. Mechanism of resistance to anticancer agents in Advances in Cancer Research,
A. Haddow and S. Weinhouse, Eds. New York, Academic Press, 1963, vol. 7, p. 129.

34. Friedkin, M. Enzymatic aspects of folic acid. Ann. Rev. Biochem. 1963, 32, 185.

35. Goldberg, I. H., and M. Rabinowitz. Actinomycin $\mathrm{D}$ inhibition of deoxyribonucleic acid-dependent synthesis of ribonucleic acid. Science 1962, 136, 315.

36. Schwartz, R., and W. Dameshek. Drug-induced immunological tolerance. Nature (Lond.) 1959, $183,1682$.

37. Schwartz, R., and J. André. The chemical suppression of immunity in Mechanism of Cell and Tissue Damage Produced by Immune Reactions, P. Grabar and P. Miescher, Eds. New York, Grune \& Stratton, 1962, p. 385.

38. Hoyer, J. R., L. W. Hoyer, R. A. Good, and R. M. Condie. The effect of 6-mercaptopurine on delayed hypersensitivity in guinea pigs. J. exp. Med. 1962, 116, 679.

39. Meeker, W. R., Jr., R. M. Condie, R. A. Good, and R. L. Varco. Alteration of the homograft response by antimetabolites. Ann. N. Y. Acad. Sci. 1960, 87, 203.

40. Smith, R. T. Immunological tolerance of nonliving antigens in Advances in Immunology, W. $\mathrm{H}$. Taliaferro and J. H. Humphrey, Eds. New York, Academic Press, 1961, vol. 1, p. 67.

41. Weiss, D. W. Inhibition of tuberculin skin hypersensitivity in guinea pigs by the injection of tuberculin and intact tubercle bacilli during fetal life. J. exp. Med. 1958, 108, 83. 